\title{
WATER FLOW IN DIFFERENT DIRECTIONS IN Corymbia citriodora WOOD
}

\author{
Thiago Campos Monteiro ${ }^{1, \diamond}$, José Tarcisio Lima ${ }^{2}$, José Reinaldo Moreira da Silva ${ }^{2}$, \\ Raphael Nogueira Rezende ${ }^{3}$, Ricardo Jorge Klitzke ${ }^{l}$
}

\begin{abstract}
This study aims to evaluate the free and bound water flows in the different axes of Corymbia citriodora wood during drying. Wood samples were taken from the inner and outer regions of the tree stem from sevenyears-old experimental plantations. The blocks were prepared for the water flow to occur in each wood axis and they were dried up to the final moisture content of $12 \%$. Free water (FWFR), bound water (BWFR) and total water (TWFR) flow rates were calculated. The relationship between loss of moisture content and time presented an exponential curve, especially in the radial and tangential wood axes. Water flow in the three wood directions presented higher FWFR than TWFR (which was higher than BWFR). Free water flow was $\sim 10$ times higher than adsorbed water flow, considering values for moisture content between $\sim 80 \%$ to $\sim 12 \%$. Free water movement in the longitudinal direction of the wood was $\sim 2$ times greater than in the radial axis and $\sim 3$ times greater than in the tangential axis. Bound water movement in the longitudinal direction of the wood was $\sim 2$ times greater than in the transverse direction. Bound water flow in the radial axis of the wood was statistically equal to the one in the tangential axis. The results indicate that the intensity of free and bound water flows changes according to the direction of Corymbia citriodora wood.
\end{abstract}

Keywords: Bound water, density, free water, moisture content, water flow rate.

\section{INTRODUCTION}

The relationship between water and wood has been scientifically studied for over a century, focusing mainly on softwoods (Engelund et al. 2013). The greater importance of hardwoods in recent years, such as those from Corymbia genus, has led to increased studies on the water-wood relationship in these species (Zanuncio et al. 2013, Zanuncio et al. 2015, Redman et al. 2016, Monteiro et al. 2017, Monteiro et al. 2018, Resende et al. 2018, Rezende et al. 2018, Brito et al. 2019, Nascimento et al. 2019).

The water flow in the wood presents variations in its physical state and form of movement (Engelund et al. 2013). The water can be divided basically into two groups (Kollmann and Côté Jr 1968, Siau 1971): 1) free or capillary water, from the liquid and gaseous phases, above the fiber saturation point (FSP); 2) bound water - adhesion or impregnation - from the gaseous phase and bound in the cell wall of the fibers, below the FSP. Eitelberger et al. (2011) report the adequate modeling for bound water, distinguishing between the two phases of water in the wood, namely bound water in the cell walls and water vapor in the lumens. Water flows in the wood are complex, as it occurs during liquid and gaseous phases (Kollmann and Côté Jr 1968), depending on whether it is above or below the FSP. At this point, the moisture content varies between 25 and 35\% (Skaar 1988).

\footnotetext{
${ }^{1}$ Professor, Federal University of Paraná, Department of Forestry Engineering and Technology, Curitiba, PR, Brazil.

${ }^{2}$ Professor, Federal University of Lavras, Department of Forestry Sciences, Lavras, MG, Brazil.

${ }^{3}$ Professor, Minas Gerais Federal Institute of Education, Science and Technology, Muzambinho, MG, Brazil.

•Corresponding author: thiago.monteiro@ufpr.br

Received: 15.05.2018 Accepted: 26.04.2020
} 
The movement of these waters occurs in different ways. The free water flow is caused by capillary forces, based on Hagen-Poiseuille's Law. In turn, the movement of the water in gaseous form (vapor) and adsorbed water occurs via the cell wall by diffusion, due to the moisture gradient (Kollmann and Côté Jr 1968, Siau 1971). This movement occurs in the different directions of the wood, with different intensities. The water flow in the axial direction is higher when compared to the transversal one (Siau 1971, Mouchot et al. 2006, Engelund et al. 2013). Mouchot et al. (2006) report that the bound water flow is more intensive in the longitudinal direction when compared to the radial and tangential directions. Siau (1971) describes that the organization of the axial anatomical structures, especially the vessels, favors the flow in the longitudinal direction. Monteiro et al. (2017) complement that, on the hand, long and wide vessel elements favor the free water movement, on the other, they reduce the bound water flow in the Eucalyptus and Corymbia logs.

Corymbia wood in Brazil is mainly used in the energy, charcoal (Peres et al. 2019) and treated wood (Lopes et al. 2018) industries. Improved permeability in wood may lead to faster, cheaper and high-quality drying, improve the energetic use of wood, ease chemical treatment, and effectively manufacture wood-polymer composites. Different techniques were used to evaluate water interaction with wood materials, including gravimetric techniques (Redman et al. 2016, Thybring et al. 2018) and apparatus for testing wood permeability to air and liquid (Silva et al. 2010, Tanaka et al. 2010, Baraúna et al. 2014). However, different techniques to evaluate hardwood permeability have only found values for the longitudinal direction and have found difficulty in measuring this parameter in the radial and tangential axes (Silva et al. 2010, Baraúna et al. 2014, Rezende et al. 2018, Brito et al. 2019).

There is still no information concerning the possible difference between free and bound water flows according to the wood axes during wood drying, especially in Corymbia. Thus, this study aimed to evaluate the flow of free and bound waters in the different directions of Corymbia citriodora specimens.

\section{MATERIAL AND METHODS}

\section{Preparation of materials and wood specimens}

Three seven-years-old Corymbia citriodora trees, located next to the municipality of Belo Oriente $\left(19^{\circ} 31^{\prime} \mathrm{S}\right.$ and $42^{\circ} 44^{\prime} \mathrm{W}$ ), state of Minas Gerais, Brazil, were collected. The spacing between the trees in the reforestation was $3 \times 3 \mathrm{~m}$. Trees were harvested, and logs from the base were removed. One central board from each $\log$ was produced using a simple vertical band saw, and four wooden scantlings were cut using a circular saw - two from the internal region and two from the external region of the stem.

Eight blocks of $30 \times 30 \times 30 \mathrm{~mm}$ were produced from each wooden scantling. Two blocks were removed from the central region of each wooden scantling to determine the wood basic density. Six blocks were cut in half ending with the dimensions of $15 \times 30 \times 30 \mathrm{~mm}$. Measurement of $15 \mathrm{~mm}$ represented the water flow axis (axial, radial or tangential) that was evaluated. Thus, each wooden scantling produced 12 drying samples, four on each axis, and each tree produced 48 samples for drying, half from the internal region and half from the external region.

\section{Methods}

Blocks for drying were produced with the dimensions of $30 \times 30 \times 15 \mathrm{~mm}$. The direction with the smallest dimension was the one in which the water flow occurred (Figure 1). The samples were identified, and their faces were waterproofed with epoxy-based adhesive, represented by hatches in Figure 1. In the same figure, the curved lines represent the growth rings in the cross-section and the arrows indicate the water flow direction. 


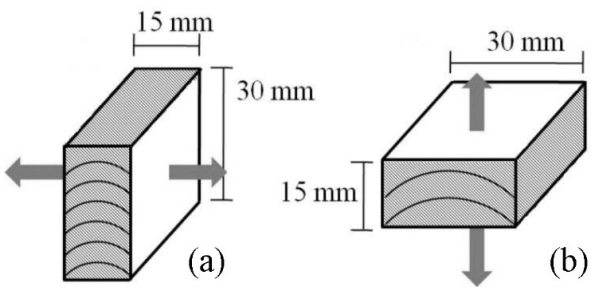

(b)

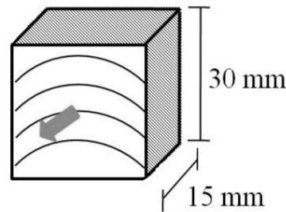

(c)

Figure 1: Scheme of the wood blocks used to evaluate the water flow in the axes of Corymbia citriodora wood. Where: (a) - Water flow in the tangential direction; (b) - Water flow in the radial direction and (c) Water flow in the axial direction.

The wood blocks were stored in an air-conditioned room, with a temperature of $20 \pm 2{ }^{\circ} \mathrm{C}$ and relative humidity of $65 \pm 5 \%$. This condition, after wood drying, generated the equilibrium moisture of approximately $12 \%$. The mass of the samples was measured using a digital electronic scale, with an accuracy of $0,01 \mathrm{~g}$, every six hours in the first week, every $12 \mathrm{~h}$ in the second week and every $24 \mathrm{~h}$ until mass stabilization. Constant mass was estimated when the difference between two successive weighings was less than $0,2 \%$ after $24 \mathrm{~h}$. After achieving constant mass in the air-conditioned room, the blocks were dried in a kiln, with forced air circulation and a temperature of $105 \pm 2{ }^{\circ} \mathrm{C}$, up to constant mass. Constant mass was estimated when the difference between two successive weighings was less than $0,1 \%$ after $24 \mathrm{~h}$. Dry masses (moisture $=0 \%$ ) were then determined on an electronic scale.

The moisture content of the samples was determined from the ratio of water mass and wood dry mass, and the basic density was determined from the ratio of wood dry mass and wood green volume, according to the standard ASTM D2395-14 (2001).

The first mass measured during drying was considered for initial moisture content (IMC). The FSP was considered equal to $30 \%$ - an average value reported in the literature for hardwoods (Skaar 1988, Berry and Roderick 2005, Engelund et al. 2013). The mass of the blocks for moisture close to $30 \%$ was considered for the FSP in the estimation of water flow rates. The mass considered as equilibrium moisture content (EMC) was the one at the end of drying when it became constant.

The mean time taken for free water outlet (FWT) - between IMC and FSP - and the mean time taken for bound water outlet (BWT) - between FSP and equilibrium moisture content - were evaluated. The sum of FWT and BWT was used as total drying time or total water flow time. Drying in mild conditions was used to prevent collapse and other drying defects. Thus, drying was partial $(\sim 12 \%)$ and not total (until $0 \%$ moisture). A graph that shows the log moisture loss as a function of time was generated.

Free water, bound water, and total water flow rates were determined for the different directions of the wood blocks, according to Equation 1, Equation 2 and Equation 3.

a) Free water flow rate:

$$
F W F R=\frac{M L f}{D i}
$$

Where: FWFR is the free water flow rate $\left(\% \mathrm{MC} \mathrm{day}^{-1}\right) ; M L f$ is the free water outlet, which is the difference between initial moisture content (IMC) and FSP (\%); $D i$ is the initial drying time up to the FSP (day).

b) Bound water flow rate: 


$$
B W F R=\frac{M L a}{D a}
$$

Where: $B W F R$ is the bound water flow rate $\left(\% \mathrm{MC}_{\text {day }}{ }^{-1}\right) ; M L a$ is the bound water outlet, which is the loss of moisture between FSP and equilibrium moisture content (EMC), (\%); Da is the final drying time up to the EMC (day).

c) Total water flow rate:

$$
T W F R=\frac{M L t}{D t}
$$

Where: $T W F R$ is the total water flow rate $\left(\% \mathrm{MC}\right.$ day $\left.{ }^{-1}\right) ; M L t$ is the free and bound water outlet, which is the difference between IMC and EMC (\%); $D t$ is the total drying time between IMC and EMC (day).

The statistical analysis of the variation of moisture as a function of drying time for the longitudinal, radial and tangential directions of the wood corresponded to an exponential model. The quality of the adjustment was evaluated by the determination coefficient $\left(\mathrm{R}^{2}\right)$. To adjust the regression models, this study used $\operatorname{lm}$ function in the R software (R Development Core Team, 2014). To test the influence of time on moisture content, Pearson's correlation test was used $(\mathrm{p}<0,05)$, and to make the response surface plots, the software Microsoft Excel (2007) was employed.

Statistical analysis was performed in the R software (R Development Core Team, 2014) using analysis of variance, and the Scott-Knott test was applied at 5\% significance to verify significant differences between the mean values. Completely casualized design was used twice: 1 ) double factorial scheme with two regions of the trunk and three water flow rates on wood (free, bound and total); the response variables were flow water rates and basic density, with 72 repetitions for each trunk region; 2) double factorial scheme with three wood axes and three flow water rates. the response variables were flow water rates, with 48 repetitions for each wood axis.

\section{RESULTS AND DISCUSSION}

The curve for the moisture loss as a function of time and the models obtained for the longitudinal, radial and tangential axes of Corymbia citriodora wood are illustrated in Figure 2.

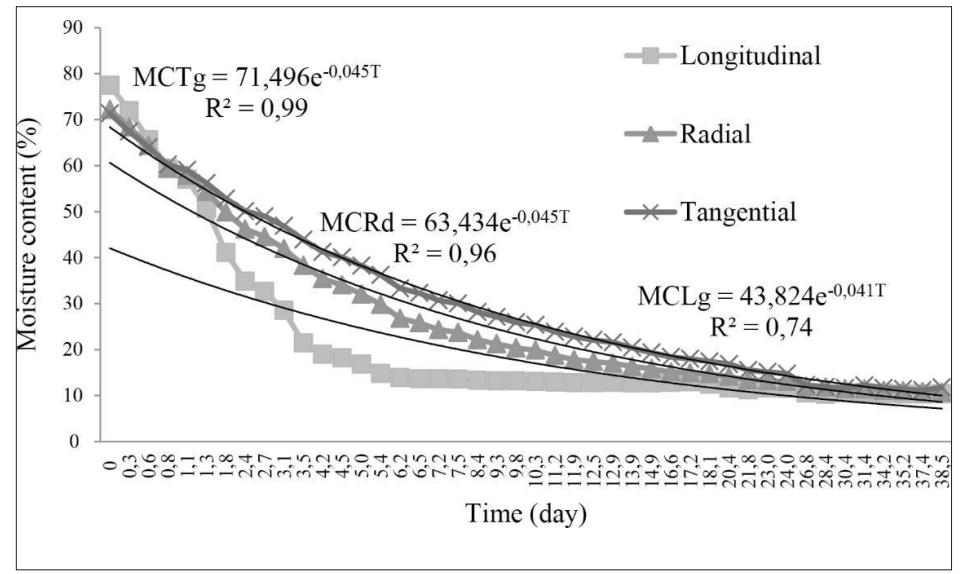

Figure 2: Curve for the moisture content as a function of drying time with a regression model for the different axes of Corymbia citriodora wood. Where: MCTg - moisture content for water flow in the tangential axis (\%); MCRd - moisture content for water flow in the radial axis (\%); MCLg - moisture content for water flow in the longitudinal axis (\%); $\mathrm{T}$ - time (day); $\mathrm{R}^{2}$ - determination coefficient. 
The conditions of the air-conditioned room where specimens were dried allowed the samples to stabilize humidity around $12 \%$ (Figure 2). The samples used to evaluate water flow in the longitudinal axis had slightly higher initial moisture (77\%) and yet lost free water rapidly when compared to samples from the radial and tangential directions, which presented average initial moisture of 72 and $73 \%$, respectively. Samples from longitudinal and radial axes spent 17,9 and $18,9 \%$ of drying time in the free water outlet, whereas specimens from the tangential direction spent $26,5 \%$ of the time in the same water flow - observed by the upper curve of the tangential direction samples in drying up to the moisture $\sim 30 \%$. It is also possible to observe the similar behavior between the radial and tangential axes after $\sim 8,4$ days of drying during the movement of the bound water.

The accuracy of the models reflects the high determination coefficient between the moisture loss of the wood samples in the different directions and the drying time (Figure 2). The increase of the drying time exponentially reduces the moisture content of the wood in all of its three axes, mainly in the radial and tangential directions, which presented higher coefficients of determination $\left(\mathrm{R}^{2}\right)$. Factors such as the anatomical structure also influence the movement of water in the wood (Siau 1971, Ahmed and Chun 2011, Monteiro et al. 2017) and may have contributed to the difference between the $\mathrm{R}^{2}$ of the radial and tangential directions and the longitudinal axis. The dimension of the piece of wood also influences the permeability (Bramhall 1971).

The high $\mathrm{R}^{2}$ of the drying models on the radial and tangential axes demonstrate the importance of drying through the radial and tangential sections of the wood. The importance of the lumber or trunk surface in drying can be demonstrated by the high $\mathrm{R}^{2}$ of the exponential models found in the studies for drying of hardwood. Eucalyptus grandis lumber dries between the initial humidity of $\sim 90 \%$ and the final humidity of $\sim 14 \%$ using two drying methods: with and without vaporization resulted in exponential models for moisture loss as a function of time with $\mathrm{R}^{2}$ equal to 0,993 and 0,998, respectively (Rezende et al. 2015). Eucalyptus and Corymbia logs with a diameter in the range of 4,3 and $20,3 \mathrm{~cm}$ showed $\mathrm{R}^{2}$ for exponential models for drying as a function of time equal to 0,$926 ; 0,921$ and 0,892 for the evaluation times of 30,60 and 90 days, respectively (Zanuncio et al. 2015). Corymbia citriodora logs with a diameter of $\sim 17,88 \mathrm{~cm}$, drying between $\sim 70 \%$ and $\sim 14 \%$, found $\mathrm{R}^{2}$ for linear models for moisture content as a function of time equal to 0,$96 ; 0,97$ and 0,95 for total log drying (between $\sim 70$ and $\sim 14 \%$ ), free water outlet (between $\sim 70$ and $\sim 30 \%$ ), and bound water outlet (between $\sim 30$ and $\sim 14 \%$ ), respectively (Monteiro et al. 2018).

Basic density and free, bound and total water flow rates in Corymbia citriodora wood showed no significant difference between the inner region, next to the heartwood and external region, close to the bark of the trunk (Table 1).

Table 1: Basic density $\left(\mathrm{kg} / \mathrm{m}^{3}\right)$, free, bound and total water flow rates $\left(\% \mathrm{MC} \mathrm{day}^{-1}\right)$ of the wood from the internal and external regions of Corymbia citriodora trunk.

\begin{tabular}{|c|c|c|c|c|c|c|c|c|}
\hline \multirow{2}{*}{ Region } & \multicolumn{2}{|c|}{ BD } & FWFF & & \multicolumn{2}{|c|}{ BWFR } & \multicolumn{2}{|c|}{ TWFR } \\
\hline & \multicolumn{2}{|c|}{$\left(\mathrm{kg} / \mathrm{m}^{3}\right)$} & \multicolumn{6}{|c|}{$\left(\%\right.$ MC day $\left.{ }^{-1}\right)$} \\
\hline Internal & 620 & ns & 11,69 & ns & 1,09 & ns & 3,26 & ns \\
\hline External & 673 & ns & 12,20 & ns & 1,24 & ns & 3,36 & ns \\
\hline Mean & 647 & & 11,95 & & 1,17 & & 3,31 & \\
\hline
\end{tabular}

ns: not significant, by Scott-Knott test at 5\% significance; BD: basic density; FWFR: free water flow rate; BWFR: bound water flow rate; TWFR: total water flow rate.

The equality of the internal and external trunk regions for basic density and water flow reflects a low variation in the wood physical properties between the internal (heartwood) and external (sapwood) regions of the trunk (Table 1). The age of seven-years-old of trees can influence this result due to the high presence of juvenile wood on the stem. As trees age and consequently form adult wood and heartwood, the differences between the trunk regions tend to accentuate. In general, the literature presents higher values of basic density in the external region of the trunk. Panshin and De Zeeuw (1980) reported that the basic density of the wood increases from the pith to the bark direction, a similar trend found by Cruz et al. (2003) for the wood of the 
Eucalyptus genus, which belongs to the Myrtaceae family - same of the Corymbia genus. For wood water flow, higher values are found close to the bark, in sapwood, than close to the pith. The heartwood, present in the internal region of the trunk, has low permeability when compared to the sapwood (Siau 1971). The presence of tyloses clogging the vessels is one of the reasons that reduce the permeability of the wood in the heartwood (De Micco et al. 2016, Helmling et al. 2018). Higher permeability values of Eucalyptus wood in the sapwood region are reported in the literature (Silva et al. 2010, Brito et al. 2019).

The mean basic density of Corymbia citriodora wood equal to $647 \mathrm{~kg} / \mathrm{m}^{3}$ (Table 1) is consistent with the literature, for example, Zanuncio et al. (2015) found values between 665 and $684 \mathrm{~kg} / \mathrm{m}^{3}$ for Corymbia citriodora wood from seven-years-old trees, and Monteiro et al. (2018) report mean values of basic density for trees of the same species and age equal to $610 \mathrm{~kg} / \mathrm{m}^{3}$. The comparison with the values of water flow in wood is more complex since few studies approach the rates of the free and absorbed water in a detailed way, as well as diverse methodologies, are used for measure permeability, for example, apparatus for testing the permeability to air and liquid in wood (Silva et al. 2010, Tanaka et al. 2010, Baraúna et al. 2014, Rezende et al. 2018, Brito et al. 2019) and gravimetric techniques (Redman et al. 2016, Thybring et al. 2018).

These techniques were used in laboratories using small wood samples. However, gravimetric techniques to measure water flow were also performed on larger pieces, such as lumbers and logs. Differences between rates may be due to species, wood density, sample dimensions, environmental conditions, and range of moisture content assessed. For instance, if drying between green conditions to equilibrium moisture (EM), or if drying between green condition and FSP or if drying between FSP and EM. Drying rates for Eucalyptus lumbers are reported in the literature: 1,$00 ; 1,50$; and $0,25 \% \mathrm{MC}$ day $^{-1}$ for total drying (between green condition and $22 \%$ ), free water outlet (between green condition and 30\%), and bound water outlet (between 30 and 22\%), respectively (Zen et al. 2019). Drying rates are equal to 4,6 and 4,0\% $\mathrm{MC}$ day $^{-1}$ for drying Eucalyptus grandis lumbers, with and without vaporization, respectively (Rezende et al. 2015).

Studies were also performed on the drying rates with Corymbia citriodora logs: logs with $1,2 \mathrm{~m}$ length dried between $\sim 76$ and $\sim 35 \%$ of moisture content after 90 days, resulting in drying rates between 0,611 and $0,637 \% \mathrm{MC}$ day $^{-1}$ (Zanuncio et al. 2015). Logs with 0,4m length, $17,88 \mathrm{~cm}$ diameter and dried between 70,3 and $14,8 \%$ of moisture content obtained the following drying rates: 0,$37 ; 0,72 ;$ and $0,17 \% \mathrm{MC}^{-1 a y}{ }^{-1}$ for total drying, free water outlet (between 70,3 and 30\%), and bound water outlet (between 30 and 14,8\%), respectively (Monteiro et al. 2018). The lower values of the total drying rate (TWFR) of Monteiro et al. (2018) can be explained by their use of pieces of wood (Corymbia citriodora logs) with larger dimensions when compared to the specimens used in this study. Bramhall (1971) reports that wood permeability decreases as sample length increases.

On average, the free water outlet (FWFR) of Corymbia citriodora wood was $\sim 10$ times larger than the bound water outlet (BWFR), according to data (Table 1). The slower flow of bound water when compared to free water flow is widely reported in the literature (Kollmann and Côté Jr 1968, Siau 1971, Engelund et al. 2013, Monteiro et al. 2018, Zen et al. 2019). The ratio between FWFR and BWFR for drying Eucalyptus lumbers was equal to $\sim 4$ times (Zen et al. 2019) and for drying Corymbia citriodora logs, with $0,4 \mathrm{~m}$ length, to $\sim 6$ times (Monteiro et al. 2018).

Differences between FWFR and BWFR can be partly explained by the anatomical structure and water transport mechanism in wood. The movement of free water in the wood, according to Kollmann and Côté Jr (1968), is caused by capillary forces, based on Hagen-Poiseuille's Law. In this period, the drying rate can be constant, and after this phase, when bound water leaves the wood, it is necessary to use more energy to remove this water. The evaporation rate is then slightly higher than the arrival velocity of the water on the surface of the wood. In this phase, the movement occurs mainly by diffusion, and the bound water moves through the cell wall due to the moisture gradient (Kollmann and Côté Jr 1968). This movement of water in the different forms occurs simultaneously in the same piece of wood. Below the FSP, there is also a difference between the water movement in the gaseous state and the bound water (Mouchot et al. 2006).

The analysis of the movement of water in the three directions of Corymbia citriodora wood shows that FWFR was significantly superior to TWFR, which was significantly higher than BWFR (Table 2). 
Table 2: Free, bound and total water flow rates for Corymbia citriodora wood.

\begin{tabular}{|c|c|c|c|c|c|c|}
\hline DWF & \multicolumn{2}{|c|}{ FWFR (\%MC day } & \multicolumn{2}{|c|}{ ) } & \multicolumn{2}{c|}{ BWFR (\%MC day } \\
\end{tabular}

DWF: direction of the water flow; FWFR: free water flow rate; BWFR: bound water flow rate; TWFR: total water flow rate; means followed by the same lower case letters in the lines and capital letters in the columns do not differ significant-

ly by the Scott-Knott test $(\mathrm{p}<0,05)$.

As shown in Table 2, free water flow was approximately 10 times higher than absorbed water flow. The tangential axis on the trunk showed a lower relationship between the free water outlet and bound water outlet ( $\sim 7$ times). This result can be explained due to the lower free water flow rates on the tangential axis of wood. The free water movement in the longitudinal axis was 1,9 times greater when compared to the radial axis and 3,2 times greater when compared to the tangential axis. The free water flow in the radial axis was 1,7 times greater than the tangential axis. The highest values for free and bound water flows in the longitudinal direction of $C$. citriodora wood are probably due to the arrangement of the anatomical elements, especially the vessels, which are mainly responsible for this fact in hardwoods (Siau 1971, Ahmed and Chun 2011, De Micco et al. 2016). These same authors report the importance of rays in the movement of water in the wood, being able to justify the higher FWFR values of the radial axis when compared to the tangential axis. Mouchot et al. (2006) found greater bound water flow and water vapor in the axial direction when compared to the radial and tangential axes on beech and spruce wood.

BWFR and TWFR values are not significantly affected by the radial or tangential direction in Corymbia wood (Table 2). Knowing the differences of permeability between the radial and tangential directions of the trunk can also cause problems in the wood processing, which can result in incomplete treatments and/or significantly variable between and within timbers or logs in a treatment facility. However, the evaluation of the water flow in the wood in radial and tangential directions is complex when compared to the longitudinal axis, since their values are smaller, often imperceptible to the technique used for measurement. On the one hand, some studies record values for air and liquid permeability of hardwood only for the longitudinal axis (Silva et al. 2010, Baraúna et al. 2014, Rezende et al. 2018, Brito et al. 2019). On the other, Tanaka et al. (2010) used the permeameter apparatus and ultrasonic treatment and found on Douglas-fir wood permeability higher values in the radial direction when compared to the tangential direction. In addition to the complexity of the measurement technique, the diffusion process of the bound water is influenced by the environment and characteristics of the wood. Monteiro et al. (2017) report that long and wide vascular elements, lower pore frequencies, thick cell wall, and pit pairs with higher apertures reduce the passage of bound water in Eucalyptus and Corymbia wood.

\section{CONCLUSIONS}

The analysis of free and adsorbed water movement in the axial, radial and tangential directions of Corymbia citriodora wood allowed the following conclusions:

The exponential model showed good adjustments for free and bound water outlet as a function of time for the different axes of Corymbia citriodora wood.

Free and bound water flow showed no significant difference between the internal and external regions of the trunk.

Free water flow was $\sim 10$ times higher than adsorbed water for wood.

Free water movement was greater than bound water flow $\sim 10,9$ times in the longitudinal and radial directions and $\sim 7$ times in the tangential direction of the wood. 
Free water movement in the longitudinal direction was $\sim 2$ times greater than in the radial axis and $\sim 3$ times greater than in the tangential axis.

Bound water movement in the longitudinal direction of the wood was $\sim 2$ times greater than in the transverse direction. Bound water flow in the radial axis of the wood was statistically equal to the one in the tangential axis.

\section{ACKNOWLEDGMENTS}

The authors thank the Wood Science and Technology Laboratory of the Federal University of Lavras (UFLA, Brazil) for supporting the experimental work. The authors also acknowledge CENIBRA - Celulose Nipo-Brasileira S.A for providing vegetal material. This study was funded by the company Vallourec Florestal Ltda.

\section{REFERENCES}

Ahmed, S.A.; Chun, S. K. 2011. Permeability of Tectona grandis L. as affected by wood structure. Wood Science and Technology 45: 487-500. http://doi.org/10.1007/s00226-010-0335-5

ASTM. 2001. Standard test methods for specific gravity of wood and wood-based materials. ASTM D2395-14. 2001. West Conshohocken.

Baraúna, E.E.P.; Lima, J.T.; Vieira, R.S.; Silva, J.R.M.;Monteiro, T.C. 2014. Effect of anatomical and chemical structure in the permeability of 'Amapá' wood. Cerne 20 (4): 529-534. http://doi.org/10.1590/0104 7760201420041501

Berry, S.L.; Roderick, M.L. 2005. Plant-water relations and the fibre saturation point. New Phytologist 168 (1): 25-37. http://doi.org/10.1111/j.1469-8137.2005.01528.x

Bramhall, G. 1971. The validity of Darcy's law in the axial penetration of wood. Wood Science and Technology 5 (2): 121-134. http://doi.org/10.1007/BF01134223

Brito, A.S.; Vidaurre, G.B.; Oliveira, J.T.S.; Missia da Silva, J.G.; Rodrigues, B. P.; Carneiro, A. C.O. 2019. Effect of planting spacing in production and permeability of heartwood and sapwood of Eucalyptus wood. Floram 26 (spe1): e20180378. http://doi.org/10.1590/2179-8087.037818

Cruz, C.R.; Lima, J.T.; Muniz, G.I.B. 2003. Variações dentro das árvores e entre clones das propriedades físicas e mecânicas da madeira de híbridos de Eucalyptus. Scientia Forestalis 64: 33-47.

De Micco, V.; Balzano, A.; Wheeler, E.A.; Baas, P. 2016. Tyloses and gums: a review of structure, function and occurrence of vessel occlusions. IAWA Journal 37 (2): 186-205. http://doi.org/10.1163/2294193220160130

Eitelberger, J.; Svensson, S.; Hofstetter, K. 2011. Theory of transport processes in wood below the fiber saturation point. Physical background on the microscale and its macroscopic description. Holzforschung 65 (3): 337-342. http://doi.org/10.1515/hf.2011.041

Engelund, E.T.; Thygesen, L.G.; Svensson, S.; Hill, C.A.S. 2013. A critical discussion of the physics of wood-water interactions. Wood Science and Technology 47: 141-161. http://doi.org/10.1007/s00226-0120514-7

Helmling, S.; Olbrich, A.; Heinz, I.; Koch, G. 2018. Atlas of vessel elements - Identification of Asian Timbers. IAWA Journal 39 (3): 249-352. http://doi.org/10.1163/22941932-20180202

Kollmann, F.P.; Coté, W.A. 1968. Principles of wood science and technology. 1st ed., ISBN: 978-3-64287930-2, 592p., Springer-Verlag Berlin Heidelberg : Germany. http://doi.org/10.1007/978-3-642-87928-9 
Lopes, D.J.V.; Paes, J.B.; Bobadilha, G.S. 2018. Resistance of Eucalyptus and Corymbia treated woods against three fungal species. BioResources 13 (3): 4964-4972. http://doi.org/10.15376/biores.13.3.4964-4972

Monteiro, T.C.; Lima, J.T.; Hein, P.R.G.; Silva, J.R.M.; Trugilho, P.F.; Andrade, H.B. 2017. Efeito dos elementos anatômicos da madeira na secagem das toras de Eucalyptus e Corymbia. Scientia Forestalis 45 (115): 493-505. http://doi.org/10.18671/scifor.v45n115.07

Monteiro, T.C.; Lima, J.T.; Silva, J.R.M.; Zanuncio, A.J.V.; Baraúna, E.E.P. 2018. Water flow evaluation in Eucalyptus and Corymbia short logs. Floram 25 (2): e20170659-e20170659. http://dx.doi. org/10.1590/2179-8087.065917

Mouchot, N.; Thiercelin, F.; Perré, P.; Zoulalian, A. 2006. Characterization of diffusionnal transfers of bound water and water vapor in beech and spruce. Maderas-Cienc Tecnol 8 (3): 139-147. http://doi. org/10.4067/S0718-221X2006000300001

Nascimento, T.M.; Monteiro, T.C.; Baraúna, E.E.P.; Moulin, J.C.; Azevedo, A.M. 2019. Drying influence on the development of cracks in Eucalyptus logs. BioResources 14 (1): 220-233. http://doi.org/10.15376/ biores.14.1.220-233

Panshin, A.J.; De Zeeuw, C. 1980. Textbook of Wood Technology: Structure, identification, properties, and uses of the commercial woods of the United States and Canada. 4.ed., 722p., McGraw-Hill Series in Forest Resources : New York, United States.

Peres, L.C.; Carneiro, A.C.O.; Figueiró, C.G.; Fialho, L.F.; Gomes, M.F.; Valente, B.M.R.T. 2019. Clonal selection of Corymbia for energy and charcoal production. Advances in Forestry Science 6 (3): 749753. http://dx.doi.org/10.34062/afs.v6i3.8293

R Development Core Team. 2014. R: a language and environment for statistical computing. R Foundation for Statistical Computing: Vienna.

Redman, A.; Bailleres, H.; Turner, I.; Perré, P. 2016. Characterisation of wood-water relationships and transverse anatomy and their relationship to drying degrade. Wood Science and Technology 50 (4): 739-757. http://doi.org/10.1007/s00226-016-0818-0

Resende, R.T.; Carneiro, A.C.O.; Ferreira, R.A.D.C.; Kuki, K.N.; Teixeira, R.U.; Zaidan, Ú.R.; Santos, R.D.; Leite, H.G.; Resende, M.D.V. 2018. Air-drying of eucalypts logs: genetic variations along time and stem profile. Industrial Crops and Products 124: 316-324. http://doi.org/10.1016/j.indcrop.2018.08.002

Rezende, R.N.; Lima, J.T.; Paula, L.E.R.E.; Hein, P.R.G.; Silva, J.R.M. 2018. Wood permeability in Eucalyptus grandis and Eucalyptus dunnii. Floram 25 (1): e20150228. http://doi.org/10.1590/21798087.022815

Rezende, R.N.; Lima, J.T.; Paula, L.E.R.; Silva, J.R.M. 2015. Efeito da vaporização na secagem de tábuas de Eucalyptus grandis. Cerne 21 (1): 37-43. http://doi.org/10.1590/01047760201521011546

Siau, J.F. 1971. Flow in wood. 1st ed., 131p., Syracuse University Press: Syracuse, United States.

Silva, M.R.; Machado, G.O.; Deiner, L.J.; Calil Jr, C. 2010. Permeability measurements of Brazilian Eucalyptus. Materials Research 13 (3): 281-286. http://doi.org/10.1590/S1516-14392010000300002

Skaar, C. 1988. Wood-Water Relations. 1st ed., ISBN: 978-3-642-73685-8, 283p., Springer-Verlag Berlin Heidelberg, Germany. http://doi.org/10.1007/978-3-642-73683-4

Tanaka, T.; Avramidis, S.; Shida, S. 2010. A preliminary study on ultrasonic treatment effect on transverse wood permeability. Maderas-Cienc Tecnol 12 (1): 3-9. http://doi.org/10.4067/S0718-221X2010000100001

Thybring, E.E.; Kymäläinen, M.; Rautkari, L. 2018. Experimental techniques for characterising water in wood covering the range from dry to fully water-saturated. Wood Science and Technology 52: 297-329. http://doi.org/10.1007/s00226-017-0977-7

Zanuncio, A.J.V.; Monteiro, T.C.; Lima, J.T.; Andrade, H.B.; Carvalho, A.G. 2013. Drying biomass 
for energy use of Eucalyptus urophylla and Corymbia citriodora logs. Bioresources 8 (4): 5159-5168.

Zanuncio, A.J.V; Carvalho, A.G.; Silva, L.F.; Lima, J.T.; Trugilho, P.F.; Silva, J. R.M. 2015. Predicting moisture content from basic density and diameter during air drying of Eucalyptus and Corymbia logs. Maderas. Ciencia y Tecnología 17 (2): 335-344. http://doi.org/10.4067/S0718-221X2015005000031

Zen, L.R.; Monteiro, T.C.; Schaeffer, W.A.; Kaminski, J.M.; Klitzke, R.J. 2019. Secagem ao ar livre da madeira serrada de eucalipto. Journal of Biotechnology and Biodiversity 7 (2): 291-298. http://doi. org/10.20873/jbb.uft.cemaf.v7n2.zen 